\title{
Comparison of the international administration in Berlin and Vienna after World War II
}

\author{
Dávid MARÓTI
}

\begin{abstract}
The legal status of both Berlin and Vienna was unique following World War II. The Allies divided both cities into sectors, however their control mechanisms and allied administrations were different. Despite the Cold War, allied cooperation in Vienna was successful and territorial integrity of the city remained, though this was not the case in Berlin.

Both cities had been detached from occupation zones and separate commands subordinated to allied military administration were set up for their operating.

This working paper aims to present the post-war international administration and legal status of Vienna and Berlin, the circumstances causing the permanent division of Berlin, and the reasons why Vienna did not come to the same fate.

This study is confined to the period from after World War II until the establishment of the Berlin blockade.
\end{abstract}

\section{Keywords}

Vienna, Berlin, international military administration, zones, sectors, agreement, occupation, legal status

I would like to say thank you to Emily Bultman for contributing to the English translation of this paper.

\section{Sectors in Vienna}

The Red Army invaded Vienna on 13 April 1945 during the last German stand surrendered at Floridsdorf Bridge. Sectoral division of the city was suggested at the beginning 1944 in the European Advisory Commission (EAC), ${ }^{1}$ however the final decision was not made until May 1945. The Soviets, in contrast to the Western Allies, had neither a military governance

1 During the Moscow Conference in October 1943, the American, the British and the Soviet ministers of foreign affairs decided on the establishment of the European Advisory Commission and its competence to elaborate occupation system of Germany and Austria after World War II. 
prepared in advance nor an expert group at their disposal with which to manage occupied territories. They only managed to issue a temporary order concerning military commands of occupied Austrian zone.

Soviet military command in Vienna took citizens into public administrative affairs and appointed a mayor (Bezirksbürgermeister) in each district who took over all administrative competencies. The main task of the reestablished civil organs was to create the conditions for daily life, security and function of the city. Moreover, it was to carry out orders of local commanders. The new city administration system consisted of eleven administrative groups (Verwaltungsgruppe) with a city council (Stadtrat) at the head of each. In the beginning, due to post-war conditions, several ad hoc decisions were made. Contacts among districts and central city administration was restored in the summer of $1945 .^{2}$

After the invasion of Vienna, the Soviets and the Western Allies had opposing views about how to restore the city borders. The Soviets were interested in restoring the borders to the state that they were in before the Anschluss in 1938. Conversely, the Western Allies were interested in restoring the borders to their post-Anschluss state of the Great Wien Empire $\mathrm{Gau}^{3}$ (Reichsgau Groß-Wien). Issues about city borders delayed the Austrian-related negotiations which started only in July 1945.

The Western Powers wanted to create borders in the above fashion, as they would have gained greater occupied territories in the Soviet zone. Furthermore, in their own Vienna sectors, they would have been able to set up more airports in reaction to a possible Soviet blockade. The matter was decided in favor of the Soviets. On 9 July in London, the Agreement of Occupation Zones and Administration of Vienna was signed (Abkommen betreffend die Besatzungszonen und die Verwaltung der Stadt Wien) - as an amendment to Control Agreement on 4 July 1945 - which finalized occupation zones of the country and sectors of Vienna. Twenty-two districts were divided into five sectors as following: ${ }^{4}$

- American sector: districts 7, 8, 9, 17, 18, 19;

- French sector: districts 6, 14, 15, 16;

- British sector: districts 5,12,13 and separately from them districts 3, 11;

- Soviet sector: districts 2, 20, 21 - the latter included district 22 of today - and separately from them districts 4 and 10.5

The first district worked for governmental affairs, was separated from other districts and sectors, and was declared an international sector. Its administration was carried out rotationally by the Allied Powers on a monthly basis. Besides Vienna, the provincial

2 FISCHER, Karl: Die Vier im Jeep: Die Besatzungszeit in Wien 1945-1955, Wien 1985, 3-4.

3 GAU-s were territorial administrative units of the Third Reich.

4 HUFSCHMIED, Richard: Sonderfall Wien? Die Alliierten und Österreich 1943-1955, in: Die Vier Mächte in Berlin: Beiträge zur Politik der Alliierten in der besetzten Stadt, BIENERT, Michael - SCHAPER, Uwe - THEISSEN, Andrea (eds.), Berlin 2007, 116.

5 The definitions of "occupation zone" and "occupation sector" are different. The former was used to describe divisions within the entire country while the latter was used within Vienna specifically. The same was true in Germany and Berlin. Vienna consists of twenty-three districts nowadays. 
capital city of Linz was also divided. However, it was only divided into the Soviet and the American zone. ${ }^{6}$

In the first days of occupation, Soviet soldiers and police assistants often recruited people on the streets as passengers for public works who were released after a few days. The city administration issued its employees identity documents in two languages to avoid being detained. In addition to public offices, factories, resistance groups, party organs and any others who possessed stamps started to issue such certificates to increase the safety-level of pass-holders. After a while, Soviet command put this method into practice as well.

Once the four powers occupied Vienna, identity passes, including identification cards, were issued in four languages and had to be carried by Viennese citizens at all times. Until 16 August 1946, crossing zone borders was allowed solely with allied travel permission (Alliierte Reiseerlaubnis). Post offices were controlled by the allies and Austrian authorities. Phones were tapped, bicycles were registered and equipped with number plates, and cyclists had to carry bicycle passes, issued in four languages.

The final phase of the occupation began after the State Treaty was signed on 15 May 1955. On 24 June, any identification cards that had been issued prior to 24 June became ineffective. On 27 July, when the French ratification document among the allies was as last deposited in Moscow, causing the State Treaty to come into force, the Allied Council held its last session and all the organs of the Allied Committee for Austria ceased working. All buildings and real estate then returned to Austrian ownership. Finally, on 14 September, the Inter-Allied Patrol concluded their duties. Coincidentally, at this time, the patrol was now using a luxurious limousine instead of a Jeep. The culmination of these events was the dissolution of a once worldwide unique institution. ${ }^{7}$

\section{Allied Control in Austria}

The Control Agreement on 4 July 1945 established the Allied Committee for Austria (Alliierte Kommission für Österreich). The Committee was responsible for coordinating allied occupation in issues related to the entire territory of Austria and Vienna.

At the head of the control mechanism stood the Allied Council (Alliierter Rat). Members of the Allied Council were commander-in-chiefs of allies and could only make decisions unanimously. Law proposals elaborated by Austrian federal legislation needed approval from the Allied Council since it was entitled to annul all law proposals.

The Executive Committee (Exekutivkomitee) was subordinated to the Allied Council and carried out its directives. The Executive Committee consisted of deputies of the four commander-in-chiefs. Subordinated to the Executive Committee were the operating professional expert groups delegated from the allies to support the work of the Executive Committee.

6 HUFSCHMIED, Sonderfall Wien? ..., 116-117.

7 FISCHER, 6-12. 
Vienna Inter-Allied Command (VIAC) was also subordinated to Allied Council and consisted of allied city commanders. Any instructions the VIAC received were obtained from the Executive Committee.

\section{Vienna Inter-Allied Command}

The First Control Agreement (Erstes Kontrollabkommen) was signed on 4 July 1945 in London. Article 11 established the Inter-Allied Command (Interalliierte Kommandantur) in Vienna which consisted of four military commanders (Kommandant) appointed by four commander-in-chiefs.

Military commanders of the city, likewise commander-in-chiefs in the Allied Council, alternated heading the Command on a monthly basis. An expert group had been created under the supervision of Inter-Allied Command, and its members were delegated by all four Allied Powers. Its assignment was to control public organs of Vienna. Inter-Allied Command was subordinated to the Allied Council and its tasks were handed down from the Executive Committee (also subordinated to Allied Council). The first informal sitting occurred on 28 July 1945 and the first official sitting took place on 17 September 1945.

As the State Treaty came into force on 27 July 1955, Inter-Allied Command terminated as well. The structure, function and activities of the Inter-Allied Command were affected by events in Berlin, however the same mistakes were not made by the Allies in Vienna. In June 1949, the ministry conference of foreign affairs used Vienna as an example for Berlin. But at this time, the Cold War had deepened so the Allied Control Council (Alliierter Kontrollrat) had not been working in Germany for months. ${ }^{8}$

\section{The Four in the Jeep - Die Vier im Jeep}

The Inter-Allied military patrol, called "The Four in the Jeep", in Vienna was a worldwide unique institution and became the symbol of the city. Only in this city was it possible that an American, a Soviet, a British and a French soldier were on common duty and patrolling to secure public order. They did so under supervision of a monthly alternating command according to the rotational system of the Inter-Allied Command and the Allied Council. The main tasks of the military patrol were to support the local police department and to take action against the people of the Allied Powers. In this latter case, shooting guns was forbidden for the Viennese police. In addition to the international military patrol, the Allied Powers also possessed national military police in their own sectors.

Every day, ten military patrols were on standby for twenty-four hours, of which four served in four occupied sectors. In district 1, a separate patrol was on duty while five other vehicles were on standby. A driver was always provided by the Americans as vehicles were their property. Contrary to common knowledge, The Four in the Jeep only used their legendary car from September 1945 until October 1946 before changing to another vehicle. In the 
beginning of 1953, the Ministry Council of the Soviet Union allowed sending other vehicles to serve in the efforts of the international patrol. ${ }^{9}$

\section{Berlin Blockade and Air Bridge from Viennese Perspective}

The events that happened in Berlin in June 1948, such as the blockade erected around the city and the establishment of the air bridge, brought anxiety to the citizens of Vienna when they feared a similar scenario happening in their own capital. News spread that the Western Powers could withdraw troops from Berlin, and that the same would happen in Vienna, and that the Soviet measures could result in war.

The use and approach of Viennese airports by Western Allies was regulated in the Zone Agreement of July 1945. The U.S. had the right to use the Tulln-Langenlebarn airport, while the use of the Schwechat airport was entitled to Great Britain and France. ${ }^{10}$ Both airports were in the Soviet zone (Lower Austria) which was a potential danger if the Soviets were to put the city under blockade. As opposed to the events in Berlin, Western Powers did not possess airports within the administrative borders of Vienna. To compensate for this lack of possession, the U.S. and Great Britain each established an air strip in Vienna in 1945. In June 1948, Americans worked out various plans to supply the city using airways. One such plan was to create a strip in the American sector in district 17. However, due to insufficient supply potential, this plan was cut from the agenda. The Americans also planned to build an airport in district 11, in the British sector. The British planned to build an airport in district 11 as well. The Americans estimated that establishing an airport in Simmering would take months. To prepare for a potential Soviet blockade, several food product storage centers (Operation Squirrel Cage - Operation Eichhörnchenkäfig) were built that would have supplied the Viennese citizens and westerns troops, if necessary. ${ }^{11}$

A Soviet blockade, like in Berlin, was not erected around Vienna. However the Americans and the British kept their plans concerning the airports top-secret, which reflected their worries. These plans would only have been made public in the event of real danger, such as a Soviet blockade; even the Austrian federal government was not informed about these plans. In 1950, plans for an airport in Simmering surfaced again after passing the fourth salary and price law, which caused demonstrations that were intended by Austrian communists to gain political support. But this time, in contrast to 1948, the Western Powers informed the Austrian federal government that they were starting the construction plans. In July 1951, leadership of federal government, called the Council of Ministers (Ministerrat), approved plans for building the American airport in Simmering. A few months later in November 1951 the Americans and the British stopped the project unexpectedly without any official announcement.

9 Ibidem, 119-120.

10 In addition to the airway connection, the Western Powers were allowed to use the railway service as well. The Americans were entitled to use the Franz-Josefs-Bahnhof (railway station). The French used Westbahnhof and the British used Aspangbahnhof. FISCHER, 5.

11 HUFSCHMIED, Sonderfall Wien? ..., 122. 
There is a significant comparison between the air supplies in Vienna and Berlin. Setting up a Soviet blockade in Vienna would have been difficult since district 1 was under international and common administration, and because some parts of the British and Soviet sectors (districts 3, 11 and districts 4, 10 respectively) ${ }^{12}$ were separated territorially. Even for the Soviets, supplying these districts would have been too difficult with a blockade. Furthermore, another important factor to note was that officially the Soviets never created plans for setting up a blockade or for permanently dividing Austria. Many emphasized the political declaration of that time that stated, "Austria is not Germany, Vienna is not Berlin!" (Österreich ist nicht Deutschland, Wien ist nicht Berlin!) and history justified it. ${ }^{13}$

\section{Sectors in Berlin}

The Siege of Berlin took place from 16 April until 2 May 1945. On 2 May, city Commander General Weidling signed surrender documents submitted by Soviet General Tschuikov in Berlin-Tempelhof. American troops had already crossed the River Elbe near Berlin on 12 April, however they did not take the offensive against it. General Eisenhower personally informed Stalin via telegram that American troops altered their way toward the south. Commander-in-chiefs of the Red Army and the United States Army met near Torgau for the first time on 25 April 1945. Berlin, located in the Soviet zone, was supposed to be divided into three parts post-capture, as planned by the British in 1944. At that time, neither the British nor the Americans estimated the possibility of a blockade surrounding the city. ${ }^{14}$

On 12 September 1944, the European Advisory Commission decided to split the Nazi Reich and Berlin into three sectors (American, British and Soviet). On this same day they created a plan for the international administration of Berlin, (Protocol of Occupation Zones in Germany and administration in Great-Berlin - Protokoll über die Besatzungszonen in Deutschland und die Verwaltung von Groß-Berlin) which was continued on 14 November with the Control Agreement (Abkommen über Kontrolleinrichtungen in Deutschland) and the Amendment on Protocol of Occupation Zones in Germany and administration in GreatBerlin (Abkommen über Ergänzungen zum Protokoll vom 12. September 1944 über die Besatzungszonen in Deutschland und die Verwaltung von Groß-Berlin).

Initially, the London Agreement on 12 September only defined districts belonging to the Soviet sector, but the western sectors had not yet been decided. ${ }^{15}$ Soviets gained the following districts:

- Pankow

- Weißensee

12 See chapter "Sectors in Vienna".

13 HUFSCHMIED, Sonderfall Wien? ..., 121-123.

14 HUFSCHMIED, Richard: Wien im Kalkül der Alliierten (1948-1955): Maßnahmen gegen eine sowjetische Blockade, Wien 2002, 15-16.

15 MASÁT, Ádám: A berlini fal és a menekültkérdés, Doctoral Dissertation, Eötvös Loránd Tudományegyetem, Bölcsészettudományi Kar, Budapest 2014, 19. 
- Prenzlauer Berg

- Mitte

- Friedrichshain

- Lichtenberg

- Treptow

- Köpenick.

During a conference on 11-19 September 1944 in Quebec, Roosevelt and Churchill agreed to divide the western occupation zones and the Berlin sectors between themselves. ${ }^{16}$ Following this decision, in the London Agreement of 14 November (Amendment on Protocol of Occupation Zones in Germany and administration in Great-Berlin), the European Advisory Commission defined the American and British districts as follows:

- United States of America:

- Zehlendorf

- Steglitz

- Schöneberg

- Kreuzberg

- Tempelhof

- Neukölln

- United Kingdom:

- Reinickendorf

- Wedding

- Tiergarten

- Charlottenburg

- Spandau

- Wilmersdorf.

In the beginning, there was no conceptualization of a French zone among the Allies. The French government did not officially represent itself at the Tehran, Yalta, or even the Potsdam Conferences. ${ }^{17}$ During the Yalta Conference on 3-11 February 1945, the Allies agreed upon the French occupation zone: it was decided that France would get one of the West Germany zones in addition to a sector in Berlin. However, Stalin insisted that the French zone and sector were to detach from the British and American zones and sectors, and the concerned governments agreed.

The London Agreement on 12 September 1944 came into force as Germany accepted unconditional surrender on 8 May 1945. On 26 July 1945, this London Agreement was amended, fixing the French zone in West Germany and the French sector in Berlin.

The Control Agreement on 14 November 1944 set up the Allied Control Council (Alliierter Kontrollrat, which is not to be confused with the Allied Council - Alliierter Rat - in Austria)

16 Ibidem, 20.

17 HUFSCHMIED, Wien im Kalkül..., 17. 
and founded the Inter-Allied Command in Berlin (officially Inter-Allied Governing Authority - Interalliierte Regierungsbehörde). The Allied Control Council and Inter-Allied Command in Berlin only made unanimous decisions. On 1 May 1945, France was added to the Control Agreement of 14 November 1944. In pursuit of these agreements, the Allies possessed supreme power through military commanders in their own zones. As members of the Allied Control Council, these military commanders were entitled to supreme power over issues concerning all of Germany. ${ }^{18}$

\section{Legal Status of Berlin after 1945}

In the Berlin Statement (Erklärung in Anbetracht der Niederlage Deutschlands und der Übernahme der obersten Regierungsgewalt hinsichtlich Deutschlands durch die Regierungen des Vereinigten Königreichs, der Vereinigten Staaten von Amerika und der Union der Sozialistischen Sowjet-Republiken und durch die Provisorische Regierung der Französischen Republik) of 5 June 1945, the Allied Powers declared their takeover of supreme power in Germany.

On 1 July, the Allies began withdrawing troops back into their own zones, as was regulated by the London Agreement on 12 September 1944. At the same time, the three Western Allies invaded West Berlin sectors. On 11 July 1945 Inter-Allied Command took over control in Berlin.

The Allies in the London and Potsdam agreements regulated legal status of Berlin. These pacts were legal sources of relations between the allied powers and occupied populations, as well as among the allies themselves.

Occupational rights were created apart from these agreements when Germany accepted unconditional surrender and when supreme power of the country was taken over by the allies. These rights originated in occupatio bellica ${ }^{19}$ rights. In international law, this means they are not to trace back to these pacts.

The legal status of Berlin was unique, as it was simultaneously set free and first invaded by the Soviet army, meaning occupational rights were under the sole possession of the Soviets until the Western Allies marched into the city in June 1945. According to the Soviet standpoint, occupational rights of the West Berlin sectors were given by the Soviet Union and could be revoked anytime. However this conception was false. The Soviets ceded their rights to the Western Powers, who then took over supreme power in West Berlin.

Consequently, the Soviets lost their occupational rights to West Berlin, which could not have been restored even if the Soviets were to change their minds. Based on the Soviets' point of view, occupational rights of the Soviets could also be revoked by Western Powers in Saxony, Thuringia or Mecklenburg areas. Legal status of Berlin could be modified with unanimous permission of all occupying powers. Therefore, occupational rights of the allies

18 MAHNCKE, Dieter: Berlin im geteilten Deutschland, Wien 1973, 34.

19 There is a difference between the definition of "occupation" and "occupation bellica". According to the latter, the aim of military occupation is to crush enemy power but not to obtain its territory. 
were separated from each other. If an invading power had given up its rights (in case an ally would have renounced occupational rights), they would not have been automatically transferred to other powers. These rights were primary (original) and not secondary (subsidiary) so they were not deduced from agreements. For that reason, they could not be violated if an agreement was violated.

In order to arrange the internal legal status of Berlin, the Inter-Allied Command published the octroyed Temporary Constitution for Great-Berlin on 13 August 1946. German politicians and jurists did not get involved while working out its details. The Temporary Constitution created a democratic self-administration that was subordinated to the InterAllied Command and military governments of each sector. The Temporary Constitution mixed elements of a state constitution (Landesverfassung) and the Prussian City Act (Städteordnung) of $1853 .{ }^{20}$

Great Berlin's ${ }^{21}$ legal status was unique because, starting in June 1945, all city territories were detached from occupation zones and were qualified as commonly invaded areas. The London Agreement on 12 September 1944 not only determined zone borders but also declared Berlin freestanding from occupation zones. Berlin, like Germany, was divided into four parts. Together, the four city commanders of Inter-Allied Command possessed supreme power over Great Berlin, and the four commander-in-chiefs of the Allied Control Council held authority over all issues concerning the entirety of Germany. Responsibilities of the Allied Control Council were to execute directives of military governors uniformly in each occupation zone and to make decision on military, political and economic issues that concerned the entire territory of Germany. They were also to control activities of German central administration in order to evolve unified occupation policy. Inter-Allied Command was responsible for the common international administration of Great Berlin and was subordinated to the Allied Control Council.

Supreme power, including legislation and administrative power, was possessed by InterAllied Command related to the Great-Berlin area. Every draft statue of the Berlin Magistracy (Magistrat) and later of the City Representative Body (Stadtverordnetenversammlung) could come into force upon approval by the Inter-Allied Command.

Members of the Allied Control Council and Inter-Allied Command had equal rights and possessed administrative competencies and supreme power on issues concerning the entire territory of Germany and Berlin. Both allied organs were only quorate when they had unanimous consent. ${ }^{22}$

20 MUSIL, Andreas - KIRCHNER, Sören: Das Recht der Berliner Verwaltung: Unter Berücksichtigung kommunalrechtlicher Bezüge, Berlin 2007, 8.

21 Great Berlin was formed by the Great Berlin Act (Gesetz über die Bildung einer neuen Stadtgemeinde Berlin), which came into force on 1 October 1920, and was responsible for merging towns (Stadtgemeinden, Landgemeinden, Gutsbezirke) all around the old city, online: http://www.verfassungen.de/de/be/berlin20.htm (Downloaded 15 March 2017) and online: http://www.tagesspiegel.de/berlin/gross-berliner-fusion-nur-los-angeles-wargroesser/1946180.html (Downloaded 4 April 2017). 


\section{Termination of Four Power Control and the Berlin Blockade}

Economic and political unity of Germany terminated in 1945. Economic trade, as well as personal and information traffic, had initially been restricted by the Soviets unilaterally, but afterwards the Western Powers made the same decisions which were followed by gradual bilateral restrictions.

One year after capitulation and invasion, occupation zones were hermetically separated from each other. Material and intellectual property and personal traffic decreased to a minimum. Four small economic units that could only keep in touch with contracts came into existence in Germany.

Failed negotiation attempts, impotence of the Allied Control Council, and Soviet ambitions to expand their "democracy" to all of Germany, forced Western Powers to finalize territorial divisions and unite West Germany to halt Soviet expansion into West Germany and West Europe. Soviets using geographical advantages sought to make connections among West Berlin and the western zones more difficult by limiting the number of available routes into the city. The Soviet measures aimed to encumber the position of Western Powers in Berlin and the integration of West Berlin to western country areas.

Political standoff between the two political blocks resulted in Soviet commander Marshal W. D. Sokolowski leaving the Allied Control Council on 20 March 1948. This event signified the last session of the Council and the end of four power administration. On 16 June 1948, Soviet delegation also left Inter-Allied Command of Berlin. ${ }^{23}$

The Berlin crisis reached its deepest point to date when the Soviets left the Inter-Allied Command. On 24 June 1948, the Soviet military government closed all overland and water, but not air, connections between the western region and West Berlin. Berlin went under a blockade. Introduction of the new Mark in West Germany on 20 June 1948 preceded the erection of the blockade. In reaction, the Soviet military government declared currency reform in the Soviet zone and, unlawfully, in all Berlin sectors on 23 June. Publishing new currency lawfully in Berlin would have also required consent of the three other Western Powers according to four power administration. ${ }^{24}$ Although it was never realized, the Western Allies insisted on regulating a new currency in a four power agreement.

In reaction to the Soviets' actions, the Western Allies expanded authority of the new Mark in West Berlin on 24 June. Expanding the new Mark in West-Berlin was just a pretext that the Soviet administration used to put all overland and water routes leading into the city under military closure. West Berlin was not only separated from the western zones but from the Soviet one as well, even East Berlin. Trade ended and power plants in East Berlin suspended power supply to the western areas of the city. The only solution for the Western Allies was to establish the air bridge.

As Soviet efforts failed to increase influence in Berlin, the blockade was announced. Their attempt to isolate West Berlin from West Germany did not succeed. On the contrary,

23 Ibidem, 40-43.

24 RENGEL, Jörg: Berlin nach 1945: politisch-rechtliche Untersuchungen zur Lage der Stadt im geteilten Deutschland, Frankfurt am Main 1993, 334. 
inhabitants of West Berlin and West Germany did not get separated but were brought closer. Western invading powers became protective powers at this time. Conflicts among the people of West Germany and the Western Allies abated, promoting the integration of western country areas.

The Berlin Blockade was dissolved with the Four Power Agreement of 4 May 1949, which terminated mutual closure - the Western Allies also cut off West Berlin from the eastern block - on 12 May and restored the status quo of 1 April $1948 .{ }^{25}$

\section{Protagonists of the Berlin Blockade}

In Berlin, "building" an air bridge was feasible, unlike in Vienna where the Western Powers did not possess an airport within the city. Upon the creation of the Berlin Blockade, the Western Allies resorted to using the Tempelhof and Gatow airports that were in the Western sectors. The former was in the American sector while the latter was in the British one. In the period of the blockade, the biggest traffic was arranged at Tempelhof Airport which meant it was the most important airport.

For the sake of long term supply and boosting capacity, a new airport called Tegel was built in the French sector for "raisin bombers" (Rosinenbomber), as Berlin inhabitants called the air bridge's airplanes. Though Tegel Airport was under French authority, the planning, execution and operation during the blockade were accomplished by Americans, as USAFE (United States Air Forces in Europe) was responsible for the air control and supplied the personnel. Tegel Airport was involved in an international affair. After its creation, it became clear that a radio tower near the airport jeopardized flight security. French authorities twice requested that the Soviet military government demolish and reinstall the tower elsewhere, however the Soviet military administration did not give any response. The French took matters into their own hands and the French city commander ordered the tower to be blown up on 16 December 1948. This explosion evoked Soviet protest. The French argued that destroying the tower was necessary in order to secure the life of the pilots. ${ }^{26}$ When questioned about how the French could blow up the tower, the commander answered, "with dynamite". ${ }^{27}$ By destroying the tower, Western Allies succeeded doubly. On one hand, the flight corridor was cleared. On the other hand, radio transmission being used for Soviet propaganda aims was limited in the eastern sector. ${ }^{28}$

In addition to the airports, British Royal Air Force (RAF) put hydroplanes into action from July until December 1948 for supplying the western areas using Wannsee, Tegeler See and River Havel as strips for landing and takeoff. ${ }^{29}$

25 MAHNCKE, 43-45.

26 HUFSCHMIED, Wien im Kalkül..., 24-28.

27 Online: http://www.tagesspiegel.de/berlin/chronik-chronik/6566154.html (Downloaded 31 March 2017).

28 Die Radionauten: Radiogeschichten: Zeitreise und Exkursionen in die Berliner RadioWelten, Norderstedt $2004,64$.

29 HUFSCHMIED, Wien im Kalkül..., 28. 


\section{Changing of Four Power Status during the Blockade}

The aims of Soviet military administration were partially fulfilled. Political abyss was getting deeper, and by means of the blockade, Soviet military government succeeded in taking complete control of East Berlin. At putsch, in November 1948, "temporary democratic Magistracy" and Friedrich Ebert Junior as governing mayor were elected.

After that, Berlin was officially divided into two parts. Inter-Allied Command again had a session on 21 December 1948 but the three western commanders declared that, in absence of the Soviet city commander, authority and resolutions of the Inter-Allied Command did not extend to East Berlin. Absence of the Soviet commander was qualified as abstention but not veto. Withdrawal of the Soviet commander in June 1948, and the reunion of Inter-Allied Command in December without the Soviet party, did not abolish the operation of this institution, which could have been realized exclusively with a four power agreement according to rules of the international law. ${ }^{30}$

\section{Conclusion}

The Austrian Control and Zone Agreements in July 1945 were signed almost one year later than was the case in Germany, making it possible for the Allies to avoid the same failures in Austria and Vienna.

Berlin had been divided into four sectors and Vienna had been divided into five. Vienna was the only city containing an international sector (district 1) which was globally unique. Berlin did not possess such a sector, which contributed to the ineffectiveness of the InterAllied Command. In Berlin, in the summer of 1945, the pitfalls of the Agreements of November 1944 became apparent. The Allies learned from their mistakes and therefore created district 1 in Vienna. Creating this district promoted cooperation within the Allied military administration, which improved its overall functioning and allowed the allies to resolve conflicts. Unlike in Germany, where local politicians and law experts had no say in political decision making and legislation, Austrian governmental organs were able to promote more of their political interests because of the international sector in Vienna. ${ }^{31}$

The decision on Vienna's legal status was made later than Berlin's, which positively shaped history for Austria and Vienna. Procrastination and conflicts about permanently drawing Vienna's administrative borders - over whether to keep Reichsgau borders of Nazi era or to restore their status as it was in 1938 - favored the Austrian capital. In Berlin, there was no dispute about city borders, as Great Berlin had already been created by the Great Berlin Act in 1920.

Unlike in Berlin, the Inter-Allied Command in Vienna had an institution called The Four in the Jeep that fulfilled their duty under a common command; not only in the international sector district 1 but in all other sectors belonging to the Allies.

30 MAHNCKE, 45.

31 HUFSCHMIED, Sonderfall Wien? ..., 117-118. 
Sectors in Berlin and Vienna were different as well. In Berlin, there was no international sector and each sector was territorially continuous. In Vienna, British districts 3, 11 and Soviet districts 4, 10 refracted the territorial integrity of the occupation sectors. This guaranteed that a Soviet blockade could not be established around the city, as a blockade would have made supplying the Soviets' own districts difficult as well. All these facts helped Vienna to avoid the permanent division that happened in Berlin.

\section{References}

Die Radionauten: Radiogeschichten: Zeitreise und Exkursionen in die Berliner RadioWelten, Norderstedt 2004.

FISCHER, Karl: Die Vier im Jeep: Die Besatzungszeit in Wien 1945-1955, Wien 1985.

Gesetz über die Bildung einer neuen Stadtgemeinde Berlin, online: http://www. verfassungen.de/de/be/berlin20.htm (Downloaded 15 March 2017).

Groß-Berliner Fusion: Nur Los Angeles war größer, online: http://www.tagesspiegel.de/ berlin/gross-berliner-fusion-nur-los-angeles-war-groesser/1946180.html (Downloaded 4 April 2017).

HUFSCHMIED, Richard: Wien im Kalkül der Alliierten (1948-1955): Maßnahmen gegen eine sowjetische Blockade, Wien 2002.

HUFSCHMIED, Richard: Sonderfall Wien? Die Alliierten und Österreich 1943-1955, in: Die Vier Mächte in Berlin: Beiträge zur Politik der Alliierten in der besetzten Stadt, BIENERT, Michael - SCHAPER, Uwe - THEISSEN, Andrea (eds.), Berlin 2007, 116-123.

CHRONIK: CHRONIK, online: http://www.tagesspiegel.de/berlin/chronik-chronik/6566154. html (Downloaded 31 March 2017).

MAHNCKE, Dieter: Berlin im geteilten Deutschland, Wien 1973.

MASÁT, Ádám: A berlini fal és a menekültkérdés, Doctoral Dissertation, Eötvös Loránd Tudományegyetem, Bölcsészettudományi Kar, Budapest 2014.

MUSIL, Andreas - KIRCHNER, Sören: Das Recht der Berliner Verwaltung: Unter Berücksichtigung kommunalrechtlicher Bezüge, Berlin 2007.

RENGEL, Jörg: Berlin nach 1945: politisch-rechtliche Untersuchungen zur Lage der Stadt im geteilten Deutschland, Frankfurt am Main 1993.

\section{Author}

Dávid Maróti

Közigazgatás-tudományi Doktori Iskola, Nemzeti Közszolgálati Egyetem

Doctoral School of Public Administration, National University of Public Service

Üllői út 82, 1083 Budapest, Hungary

maroti.david90@gmail.com 